\title{
Transfection of Adherent HEK293-EBNA1 Cells in a Six-Well Plate with Branched PEl for Production of Recombinant Proteins
}

\author{
Roseanne Tom, Louis Bisson, and Yves Durocher
}

This protocol was adapted from "Transient Expression in HEK293-EBNA1 Cells," Chapter 12, in Expression Systems (eds. Dyson and Durocher). Scion Publishing Ltd., Oxfordshire, UK, 2007.

\section{INTRODUCTION}

Fast and efficient production of recombinant proteins (r-proteins) remains a major challenge for the academic and biopharmaceutical communities. Pure r-proteins are often required in large amounts (hundreds of milligrams to gram quantities) when being developed as biotherapeutics, or in smaller quantities (milligrams) for high-throughput screening campaigns and structural or functional studies. Mammalian cells are often preferred over prokaryotic systems when expressing cDNAs of mammalian origin due to their superior capability to conduct elaborate post-translational modifications. Largescale transfection of mammalian cells is now establishing itself as a "must-have" technology in the scientific community, as it allows the production of milligram to gram quantities of r-proteins within a few days after cDNA cloning into the appropriate expression vector. Although calcium-mediated large-scale transfection is very effective, polyethylenimine (PEI) is much easier to use: It binds to and precipitates DNA efficiently and the resulting DNA-PEI complexes are suitable for efficient transfection of mammalian cells. In particular, the branched isoform of PEI works well for adherent cells, as it promotes their attachment to the plastic surface. It is thus very useful in experiments requiring multiple medium exchanges or washing steps following transfection. Also, when used in conjunction with sixwell CellBIND plates, branched PEI can be used to adhere transfected cells when establishing stable cell lines. This protocol describes the steps needed for successful transfection of HEK293 cells adapted to serum-supplemented or serum-free medium in adherent culture using branched PEI.

\section{RELATED INFORMATION}

A number of protocols are available for large-scale transfection of mammalian cells for production of milligram to gram quantities of r-proteins (e.g., Jordan et al. 1998; Schlaeger and Christensen 1999; Durocher et al. 2002; Baldi et al. 2005). Additional protocols can be found in this issue, including Transfection of HEK293-EBNA1 Cells in Suspension with Linear PEI for Production of Recombinant Proteins and Transfection of HEK293-EBNA1 Cells in Suspension with 293fectin for Production of Recombinant Proteins. For a method to purify His-tagged transfected proteins, see Purification of His-Tagged Proteins Using Fractogel-Cobalt (this issue).

\section{MATERIALS}

CAUTIONS AND RECIPES: Please see Appendices for appropriate handling of materials marked with $\langle$ ! $\rangle$, and recipes for reagents marked with $<\mathbf{R}>$. 


\section{Reagents}

$293 \mathrm{E}$ cells, maintenance (in T-flask or shake flask)

See Culture of HEK293-EBNA1 Cells for Production of Recombinant Proteins (this issue) for preparation. The presence of $\mathrm{G} 418$ does not interfere with transfection.

Calf serum, cosmic (HyClone)

Thaw the frozen serum thoroughly at $37^{\circ} \mathrm{C}$. Heat-inactivate for $30 \mathrm{~min}$ in a $56^{\circ} \mathrm{C}$ bath, swirling the bottle occasionally for thorough heat distribution. Store aliquots at $-20^{\circ} \mathrm{C}$.

$<$ !>G418, $50 \mathrm{mg} / \mathrm{mL}$ stock solution (Invitrogen)

LC-SFM medium (Invitrogen)

Supplement with $1 \%(\mathrm{v} / \mathrm{v})$ heat-inactivated calf serum and $50 \mu \mathrm{g} / \mathrm{mL} \mathrm{G418}$ prior to use.

$<\mathbf{R}>$ Phosphate-buffered saline (PBS)

$<\mathrm{R}>$ Polyethyleneimine $(\mathrm{PEI})$, branched $(1 \mathrm{mg} / \mathrm{mL})$

Plasmid DNA of interest, purified

Prepare using CSH Protocols articles Preparation of Plasmid DNA by Alkaline Lysis with SDS: Maxipreparation or Preparation of Plasmid DNA by Large-Scale Boiling Lysis.

Plasmid, fluorescent protein-expressing (optional; see Step 8)

Adding a plasmid encoding a fluorescent protein (e.g., green fluorescent protein [GFP]) to 5\% in the transfection mixture does not significantly alter expression of the gene of interest and allows visual (or quantitative, if using flow cytometry) confirmation of transfection efficiency. A few GFP-positive cells can be detected as early as 3-4 $\mathrm{h}$ post-transfection using a fluorescence microscope.

Pluronic F-68, 10\% stock solution (w/v) (Invitrogen)

TN1 medium, prewarmed (e.g., FreeStyle medium or LC-SFM containing 20\% [w/v] Tryptone N1 [Organotechnie]) (optional; see Step 13)

Supplement with $0.1 \%(w / v)$ Pluronic F-68 and filter-sterilize prior to use.

\section{Equipment}

Containers, plastic (e.g., Tupperware)

Hemocytometer

Incubator preset to $37^{\circ} \mathrm{C}$, humidified, $5 \% \mathrm{CO}_{2}$

Microscope, fluorescence (optional; see Step 8)

Paper towels

Plates, six-well, disposable (CellBIND; Corning)

Tubes, 15-mL

Vortex mixer

\section{METHOD}

Although the protocol described here uses a DNA:PEI ratio of 1.5:2, the ratio selected for production should be determined by testing various ratios in six-well plate experiments. These small-scale tests must include regular samplings to determine the optimal harvest periods.

1. Warm the LC-SFM culture medium to $37^{\circ} \mathrm{C}$.

2. Remove the cell maintenance T-flask from the incubator. Dislodge the cells by gently tapping the side of the flask

This is not necessary if the maintenance cultures are in shake flasks.

3. Remove a cell aliquot to determine cell density and viability using a hemocytometer.

4. In a $15-\mathrm{mL}$ tube, dilute the cells to $2.5 \times 10^{5}$ cells $/ \mathrm{mL}$ in a volume of $12 \mathrm{~mL}$ of medium.

This can be scaled down to $1 \mathrm{~mL}$ in 12-well plates.

5. Add $1.8 \mathrm{~mL}$ of cells to each of the six wells. Transfer to the incubator. Culture for $24 \mathrm{~h}$. 
To minimize medium evaporation, put the plates in a plastic container lined with a wet paper towel to preserve humidity. "Trap" some $\mathrm{CO}_{2}$ in the container before closing the lid.

6. On the day of transfection, warm the PBS to $25^{\circ} \mathrm{C}-37^{\circ} \mathrm{C}$. Thaw the DNA and PEI.

7. Aliquot $100 \mu \mathrm{L}$ of PBS to each of six $1.5-\mathrm{mL}$ tubes.

8. Add $3 \mu \mathrm{g}$ of DNA to each tube. Vortex.

To evaluate transfection efficiency, add a GFP expression plasmid at 5\% of the final DNA content used. A reasonable indicator of successful transfection is when the percentage of GFP-positive cells is between $30 \%$ and $50 \%$ by 48-72 h post-transfection.

9. To another 1.5-mL tube, add $672 \mu \mathrm{L}$ of PBS. Add $28 \mu \mathrm{L}$ of branched PEl solution. Vortex.

10. Add $100 \mu \mathrm{L}$ of PEl solution to each DNA-containing tube. Vortex immediately (three times, $3 \mathrm{sec}$ each) after PEI addition.

Compare different DNA:PEI ratios to see whether different lots and/or production batches affect transfection efficiency and productivity. Each new PEI preparation must be tested.

11. Incubate for $15 \mathrm{~min}$ at room temperature.

12. Remove the six-well plate from the incubator. Add the DNA/PEI mixture to each well and swirl the plate. Return the plate to the incubator.

13. For secreted protein production, add $50 \mu \mathrm{L}$ of prewarmed TN1 medium at 24-48 h post-transfection to each of the six wells. Return the culture to the incubator.

The final TN1 concentration in the culture(s) should be $0.5 \%(w / v)$. TN1 supplementation is not necessary for intracellular protein production.

14. Harvest the r-proteins:

\section{For intracellular r-proteins}

i. Harvest the cells at $48-72 \mathrm{~h}$ post-transfection.

Establish the best harvesting time by performing an expression kinetics study.

For secreted r-proteins

ii. Harvest the supernatants between 96 and $168 \mathrm{~h}$ post-transfection as long as the culture viability is high and the product titer is increasing.

Because culture viability decreases with time, it is important to harvest when the viability is relatively high (i.e., greater than $75 \%$ ) to protect the r-protein from proteolytic degradation.

See Troubleshooting.

\section{TROUBLESHOOTING}

Problem: The transfection does not work.

[Step 14]

Solution: Consider the following:

1. Make sure the cells are in exponential growth phase for transfections. If the culture grows to higher-than-prescribed transfection densities, medium nutrient depletion and metabolic byproducts will compromise the transfection.

2. Anti-clumping agents such as dextran sulfate can inhibit transfection.

3. DNA plasmid quality may be inadequate. Check for contaminants by $A_{260} / A_{280}$ ratio readings; acceptable values range between 1.80 and 1.95. In addition, the DNA plasmid can be digested and run on an agarose gel to verify its integrity (it should be mostly in a supercoiled form) and/or to detect RNA contamination.

4. Monitor cell line productivity occasionally by transfecting the cells with an easily measured protein such as secreted alkaline phosphatase or GFP. Low transfection efficiencies are readily indicated when the percentage of GFP-positive cells is below $30 \%$ by $48 \mathrm{~h}$ post-transfection. Also, for each new medium or reagent lot, monitor transfection efficiencies using six-well plate assays. 


\section{REFERENCES}

Baldi, L., Muller, N., Picasso, S., Jacquet, R., Girard, P., Thanh, H.P., Derow, E., and Wurm, F.M. 2005. Transient gene expression in suspension HEK-293 cells: Application to large-scale protein production. Biotechnol. Prog. 21: 148-153.

Durocher, Y., Perret, S., and Kamen, A. 2002. High-level and highthroughput recombinant protein production by transient transfection of suspension-growing human 293-EBNA1 cells. Nucleic Acids Res. 30: E9. doi: 10.1093/nar/30.2.e9.
Jordan, M., Köhne, C., and Wurm, F.M. 1998. Calcium-phosphate mediated DNA transfer into HEK-293 cells in suspension: Control of physicochemical parameters allows transfection in stirred media. Transfection and protein expression in mammalian cells. Cytotechnology 26: 39-47.

Schlaeger, E.-J. and Christensen, K. 1999. Transient gene expression in mammalian cells grown in serum-free suspension culture. Cytotechnology 30: 71-83. 


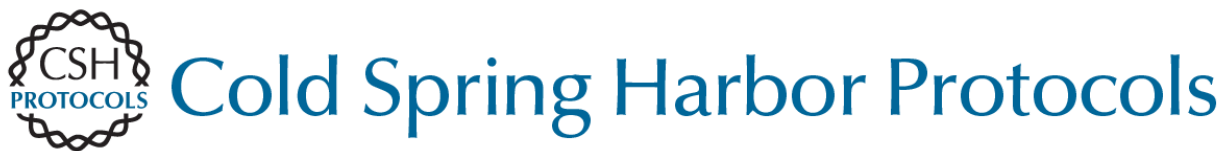

\section{Transfection of Adherent HEK293-EBNA1 Cells in a Six-Well Plate with Branched PEI for Production of Recombinant Proteins}

Roseanne Tom, Louis Bisson and Yves Durocher

Cold Spring Harb Protoc; doi: 10.1101/pdb.prot4978

\begin{tabular}{rc}
\hline $\begin{array}{r}\text { Email Alerting } \\
\text { Service }\end{array}$ & Receive free email alerts when new articles cite this article - click here. \\
\hline $\begin{aligned} \text { Subject } \\
\text { Categories }\end{aligned}$ & Browse articles on similar topics from Cold Spring Harbor Protocols. \\
& Analysis of Protein Expression in Cultured Cells (57 articles) \\
& Cell Biology, general (1382 articles) \\
& Cell Culture (301 articles) \\
& DNA Delivery/Gene Transfer (344 articles) \\
& DNA Delivery/Gene Transfer, general (341 articles) \\
& Expression of Cloned Genes (80 articles) \\
& High-Throughput Analysis, general (155 articles) \\
& Non-Viral Methods (226 articles) \\
& Protein Expression and Interactions (93 articles) \\
& Proteins and Proteomics, general (575 articles) \\
& Proteome Analysis (56 articles) \\
\hline
\end{tabular}

